\title{
Does Liquidity Management Affect Profitability in Selected Nigerian-Quoted Manufacturing Firms?
}

\author{
Matthew Adeolu Abata*, Stephen Oseko Migiro \\ College of Law and Management, University of KwaZulu-Natal, Durban, South Africa \\ *abatam@ukzn.ac.za
}

\begin{abstract}
This study examined the nexus between liquidity management and profitability in selected Nigerian-quoted manufacturing firms. Many business failures have been recorded over the years due to inability to balance the link between liquidity and profitability. Descriptive research design was employed to analyze the data gathered from 2004 to 2014 . The study found a positive relationship between credit policy, return on equity and return on capital employed. It equally found that operating cash flow and cash conversion cycle are negatively related to all the metrics of profitability. The study therefore recommends among others, that managers should strive to achieve a reasonable level of profit to optimize shareholders' wealth and keep the firms in business. Also, managers should effectively manage account receivables and inventory at optimal level to avoid tie down liquid assets unnecessarily. Investors should pay close attention to firms' operational cash flow in order to access their true state before committing their funds.
\end{abstract}

\section{Keywords: Liquidity, Profitability, Credit policy, Cash conversion cycle and Return on assets}

\section{Introduction}

A firm's financial manager should be able to take effective financial management decisions otherwise illiquidity becomes inevitable. Such decisions include investment, financing and dividend policy decisions (Barclay and Smith, 1988; Preston and Post, 1981). Liquidity connotes the firm's ability to meet its short-term obligations which are within one accounting year. The short- term equally reflects the operating cycle: buying, manufacturing, selling, and collecting. The firm that cannot service its creditors as at when due and continue to dishonor its obligations to the suppliers of goods, services, and credits can be declared insolvent. Liquidity management involves planning and controlling current assets and liabilities in such a manner that eliminates the risks of inabilities to meet due short term obligations, on the one hand, and avoidance of excessive investment in these assets, on the other hand (Priya \& Nimalathasan, 2013). Liquidity management is significant to both internal and external analysts because of its relationship with day-to-day operations of businesses(Bhunia, 2011). Technically, it means the firm's continuous ability to meet maturing obligations. Profitability is the ability of a firm to generate revenue that exceeds its liabilities. The main goal of a business is making profit which is the reward for risk-taking. Business may have other goals but if they are not profitable then they will be declared bankrupt. The significance of profit in a business is without question. Profit is essential for business survival and growth, providing a platform for future contingencies, is a yardstick to test business efficiency, provide internal sources of funding for expansion and development and is an inducement to investment that is conducive for employment creation.

Every user of financial information is interested in these two items. Although the ultimate goal of any firm is to maximize profit, the preservation of firm's liquidity is a key objective as well. The challenge is that any profit increase at the expense of liquidity can pose serious challenges to the firm. Therefore, there must be a trade-off between these two goals. One goal should not be pursued at the expense of the other because both are necessary. If one does not care about profit, one cannot survive indefinitely. On the other hand, if one does not care about liquidity, one may face the problem of insolvency or bankruptcy. For these reasons management of liquid assets should be given appropriate consideration since it will ultimately affect the profitability of the firm. In the light of the above, it must be mentioned that there is no standard norm for liquidity levels to be maintained at a particular time. It depends on the nature of the business, scale of operations, location of the business and numerous other factors. Every user of financial statement has interest in the liquidity position of the firm. Suppliers will check the liquidity position of the company before selling goods on credit to be sure of payment. Workers are also interested in the liquidity to know whether 
the firm can meet its employee-related obligations while shareholders are interested in understanding liquidity position due to its impact on the profitability of the firm (CEBS, 2009). From the above it can be inferred that managers can generate profits for their companies by appropriately managing the cash conversion cycle and by keeping accounts receivables at an optimal level (Gill, Biger \& Mathur,2010).

Few prior studies have been conducted in Nigeria that address liquidity management and its impact on firm's profitability (Agbada \& Osuji, 2013; Egbide, Uwuigbe \& Uwalomwa, 2013; Owolabi, Obiakor \& Okwu, 2011; Ezejiofor, Adigun \& John-Akamelu, 2015 and Umobong, 2015) but no prior studies have addressed this nexus between liquidity and profitability in these five oldest and highest employers of labour manufacturing firms in Nigerian capital market. Owolabi, Obiakor and Okwu (2011) studied the liquidity-profitability relationship in business organization and found liquidity and profitability positively related and reinforcing each other. Agbada and Osuji (2013) examined the efficacy of liquidity management and bank performance in Nigeria using survey design on 300 bank employees in Asaba and Lagos only. Egbide, Uwuigbe and Uwalomwa (2013) investigated liquidity management and profitability in some manufacturing firms in Nigeria and found current ratio and profitability insignificantly positively related while cash conversion period and profitability insignificantly related. Ezejiofor, Adigwe and john-Akamelu (2015) investigated the credit management on liquidity and profitability position of 2 manufacturing firms. He established liquidity management and profitability association and a significant association between liquidity position and debtor's turnover. They equally claimed that credit policy can affect corporate profitability. Umobong (2015) analyzed the impact of liquidity and profitability ratios on growth of profits in Pharmaceutical firms in Nigeria and found significant contributions of all the variables to profit growth.

The relevance of this study stemmed from the fact that Nigeria has adopted the International Financial Reporting Standard (IFRS) at both public and private sectors. This makes all reported financial statement open to the world and firms that performed below expectation will be unable to borrow in time of need neither will they be able to raise fund from the capital market. Secondly, the findings from this study is expected to have positive implications in terms of coming up corporate policies and reforms that will enhance close monitoring of operational activities in quoted firms. Besides, financial analysts, shareholders and management of Nigerian manufacturing firms stand to benefit immeasurably through the application of the recommendations from this study. According to Ilori (2013) one major component of indigenous and foreign business failures in Nigeria is the absence of best corporate governance practices manifested principally in the management of liquid assets and profit. For instance, Nigeria Airways, Kaduna Textiles, Concord group, Lion of Africa Insurance, Oceanic Bank, Societe Generale Bank Nigeria among others failed in business due to low cash reserves and poor management of funds (Nwaigbene, 2015). Despite such failures, numerous corporate organizations have not realized the need to balance the nexus between liquidity management and corporate profitability. This negligence has led to the closure of many manufacturing companies in Nigeria. Many corporate managers till date still placed undue priority on profit maximization without adequately managing the liquid assets that will enhance the profit. This study therefore intends to bridge this gap by establishing the extent of the relationship existing between the companies' credit policy and the firms' profitability and also analyze the significant level of the relationship between cash flow management and the firms' profitability.

\section{Literature Review}

Conceptual: This study drew its conceptual foundation from the Moulton (1918) Shift ability liquidity and Schumpter (1943) profitability theories. Eljelly (2004) define liquidity management as the conversion of assets into cash during the business normal course and to have regular and consistent flow of cash to meet external current liabilities as and when due and also to ensure availability of money for the day to day business operations. Moulton (1918) claimed that the problem of liquidity is not usually a problem but it is shifting of assets without material loss. To maintain minimum reserves does not warrant relying on maturing bills but maintaining the quantity of assets which can be shifted to other establishments whenever necessary. Schumpeter (1939) postulated the theory of innovative profits. He stated that profits depend upon creating new fields of productive endeavors to add to and restructure the established circular flow of income. It held that market power is the cause of innovation by providing resources and safeguarding against the potential downside of risk-taking activities. Schumpeter (2008) distinguished between the profits which are as a result 
of the market power of monopolistic or oligopolistic firms and the profits they earn from their capacity to innovate, and insisted on the priority of the latter over the former. The theory equally accommodated the significance of inter-company technological cooperation as well as competition. In the face of growing technological complexities, innovation always incorporates element of imitation.

Numerous authors have analyzed the nexus between liquidity management and corporate profitability by using different statistical tools as linear and multiple regressions. Mixed results have been found across the globe. While some found them to be positively related, other found them to be negatively related at different significant levels. However, most of the empirical studies established liquidity and profitability as essential for corporate survival and have found them to be universally associated with each other (Abuzarand, 2004; Matheva, 2010; Owolabi \& Obida, 2012 and Ajathan, 2013). Empirical studies are presented to identify the different research gaps. Oladipupo and Okafor (2013) investigated the relationship between a firm's working capital management practice on its profitability and dividend payout ratio using Ordinary least square and Pearson product correlation technique. Twelve Nigerian-quoted manufacturing companies were sampled from 2002 to 2006 resulting in a negative relationship between profitability and working capital with debt ratio as most significant at $5 \%$ confidence level. A positive relationship was found between profitability and dividend payout on one hand and a positive relationship between dividend payout and working capital on the other hand. Uremadu, Egbide, and Enyi (2012)) studied the link among working capital management, liquidity and corporate profitability in 25 quoted firms in the manufacturing companies in Nigeria from 2005 to 2006. Using the descriptive and an Ordinary Least square method, a positive link was found between inventory conversion period and debtors collection period on one hand but a negative effect between cash conversion period, creditors' payment period and return on assets (profitability) on the other hand.

Abuzarand (2004) examines liquidity-profitability tradeoff using 29 manufacturing and agricultural firms in the Saudi stock exchange from 1996 to 2000. Using Pearson correlation coefficients, he found a positive relationship between size of the firm and profitability, a significant negative relationship between current ratios and net operating income, as well as negative effect between profitability and liquidity. Using regression analysis, a positive and significant relationship was found between cash gap and size (LOGS) while current ratios coefficients are not significant. Working capital management components influence on profitability was examined by Mathuva (2010). A sample of 30 listed firms on the Nairobi Stock Exchange (NSE) was investigated from 1993 to2008. A highly significant negative relationship between the debtor's collection period and profitability was found. This means that it takes the more profitable firms the shortest time to collect cash from their customers. Findings showed the existence of a highly significant positive link between the inventory conversion period and profitability. Also, a significant positive relationship exists between the creditors' average payment period and profitability. In Ghana, Akoto, Awunyo-Vitor, and Angmor (2013)) investigated the nexus between working capital management practices and profitability of 13 listed manufacturing firms for a period 2005 to 2009 using regression analysis. A significant negative relationship was found between Profitability and Accounts Receivable Days. They equally found a significant positive relationship between cash conversion Cycle, Current Asset Ratio, Size, and Current Asset Turnover and profitability.

In Kenya, Makori and Jagongo (2013) investigated the link between working capital management and firm profitability in the listed manufacturing and construction firms using regression analysis. They found a negative relationship between ROA and ACP, CCC and leverage on one hand and a positive relationship between ROA and ICP, APP, GROWTH and size. Owolabi and Obida (2012) studied the nexus between liquidity management and corporate profitability in 12 listed manufacturing firms in Nigeria from 2005 to 2009 using descriptive analysis. They found that liquidity management measured in term of credit policies, cash flow management and cash conversion cycle have a significant impact on corporate profitability. A causative relationship was found between ROA, ROE ROI and the corporate DCP, CPP and OCR. Abuzarand (2004) evaluated the relationship between profitability and liquidity on a sample of listed companies in Saudi Arabia. Significant negative relation was found between the firm's profitability and its liquidity level, as measured by current ratio. However, at the industry level, however, it was found that the cash conversion cycle is of more important than the current ratio that affects profitability as a measure of liquidity. In America, Gill, Bier and Mathur (2010) examined the relationship between working capital management and profitability on a sample of 88 listed firms on the New York Stock Exchange for a period of 2005 to 2007. A 
statistically significant link was found between the cash conversion cycle and profitability (gross operating profit).

In Sri Lanka, Ajanthan (2013) investigated the link between dividend payout and profitability of 16 listed Hotels and Restaurant from 2008 to 2012. He employed Regression and Correlation analyses and established a positive relationship between dividend payout and profitability. It was established that a significant relationship between revenue and profitability exist among the listed hotels and restaurant companies. In Saudi Arabia, Almazari (2013) analyzed the relationship between firms' working capital management (WCM) and their profitability for 13 companies including 8 listed Saudi cement manufacturing companies between 2008-2012. Employing Pearson correlation and linear regression analyses, findings showed that the current ratio was the key liquidity measure which affected profitability in Saudi Cement industry. The study equally found a negative relationship between debt financing and profitability. On the firm size and its profitability, a positive relationship was found while a high degree of association was found between the working capital management and profitability. From Nestle Nigeria Plc and Cadbury Nigeria Plc., IKpefan and Owolabi (2014) examined the relationship between working capital management and profitability. A negative relationship was found between the Debtors collection period and Return on equity (ROE), while a positive relationship between current ratio and Return on capital employed (ROCE) and a negative relationship between liquidity and profitability.

\section{Methodology}

\section{Operational Definitions of variables}

\begin{tabular}{ll}
\hline Variables & Operational Definitions \\
\hline $\begin{array}{l}\text { Dependent Variables : } \\
\text { Return on Assets }\end{array}$ & Net Income/Average Total Asset*100 \\
$\begin{array}{l}\text { Return } \\
\text { on Equity }\end{array}$ & $\begin{array}{l}\text { Profit after tax/ Equity* } 100 \\
\text { Returns on Capital Employed } \\
\text { Independent Variables: }\end{array}$ \\
$\begin{array}{l}\text { Predit policy } \\
\text { Cash Conversion Cycles }\end{array}$ & $\begin{array}{l}\text { Debtors Collection Period Minus Creditors Payment Period } \\
\text { Dperating Cash Flow }\end{array}$ \\
$\begin{array}{l}\text { Control Variable: } \\
\text { Size }\end{array}$ & Natural Logarithm of Operating Cash Flow \\
\hline
\end{tabular}

The models below were developed to test the formulated hypothesis:

\section{Model I}

$\mathrm{ROA}=\beta_{0}+\beta_{1}(\mathrm{CP})+\beta_{2}(\mathrm{CCC})+\beta_{3}(\mathrm{NLOCF})+\beta_{4}(\mathrm{SIZE})+\mu$

\section{Model II}

$\mathrm{ROE}=?_{0}+\mathrm{Q}_{1}(\mathrm{CP})+\mathrm{Q}_{2}(\mathrm{CCC})+\mathrm{T}_{3}(\mathrm{NLOCF})+?_{4}(\mathrm{SIZE})+\mu$

Model III

$\mathrm{ROCE}=\lambda_{0+} \lambda_{1}(\mathrm{CP})+\lambda_{2}(\mathrm{CCC})+\lambda_{3}(\mathrm{NLOCF})+\lambda_{4}(\mathrm{SIZE})+\mu$

Where: $\mathrm{y}$ is $\beta_{0}$, ? ${ }_{0}$ and $\lambda_{0}$ are the intercepts

$\beta_{1},{ }_{1}$ and $\lambda_{1}$ are the slopes

$\mu$ is stochastic error term

ROA represent Return on Asset

ROCE represent Return on Capital Employed

ROE represent Return on Equity

CP represents Credit Policy

OCR represents Natural Logarithm of Operating Cash flow Ratio

CCC represents Cash Conversion Cycle 
An explanatory research design was adopted to guide in the collection and analysis of data. Five (5) manufacturing companies were selected. High industry standing coupled with impressive historical track records of performance underpinned the rationale for the selection. These companies are: PZ Nigeria Plc, Guinness Nigeria Plc, Nigeria Breweries Plc, Lafarge Wapco Nigeria Plc and Dangote Sugar Nigeria Plc. Secondary data were collected from the annual reports of these companies. The data gathered spanned 2004 to 2014, a period of eleven (11) years. The data were pooled into a panel that facilitated robust analyses. Key properties of the data were described with the aid of descriptive statistical techniques of mean and standard deviation. Jarque-Bera statistics were used to test the normality or otherwise of the data. While correlation analysis was also employed to determine the relationships between the variables of interest, multiple regression analysis was used to test the formulated hypotheses at $5 \%$ level of confidence. All these analyses were aided by E-views version 9 . The independent variable is liquidity management while the dependent variable is profitability. In line with cognate studies, liquidity management is proxied by a cash conversion cycle. Credit policy and operating cash flows were employed as additional indices of liquidity. Profitability is measured using returns on assets, returns on equity, return on capital employed and return on investments. The use of these four measures of profitability was geared at determining the stability or instability of the impact of liquidity across different parameters of profitability. It is worthy of note that Control variable of size was also employed.

\section{Results}

Descriptive Statistics: The results in table one (1) revealed that the average credit policy for the five manufacturing companies during the period of review is 39.89 days, with a standard deviation of 49.83 days. This suggests that creditors' payment periods for all the selected companies, on average, was higher than the debtors' collection period by a period of one month and nine days. The implication of this finding is that these manufacturing companies received more favorable credit terms from their suppliers than what they advanced to their customers. Also, the average cash collection period is 12 days, meaning that it takes an average of 12 days for the companies to convert their sales into cash. The companies recorded a higher return on equity than other metrics of profit. The Jarque-Bera coefficients and their probabilities indicated that the distribution of the data is normal.

Table 1: Descriptive Statistics on Variables

\begin{tabular}{lccrrrrr}
\hline & \multicolumn{1}{l}{ CP } & \multicolumn{1}{l}{ CCC } & LNOCF & \multicolumn{1}{l}{ ROA } & \multicolumn{1}{l}{ ROE } & \multicolumn{1}{l}{ ROCE } & \multicolumn{1}{l}{ SIZE } \\
\hline Mean & $(39.89)$ & 11.68 & 16.27 & 32.71 & 57.32 & 31.87 & 17.97 \\
Median & $(33.17)$ & 8.13 & 16.47 & 25.85 & 28.79 & 31.20 & 18.09 \\
Maximum & 72.51 & 107.94 & 18.63 & 228.19 & 532.32 & 108.32 & 19.67 \\
Minimum & $(224.24)$ & $(182.10)$ & 11.45 & 7.49 & 5.89 & $(0.69)$ & 13.53 \\
Std. Dev. & 49.83 & 47.69 & 1.40 & 32.13 & 86.31 & 21.09 & 1.01 \\
Jarque-Bera & 262.46 & 401.66 & 445.18 & $1,410.65$ & 716.69 & 627.16 & 315.34 \\
Probability & 0.20 & 0.35 & 0.42 & 1.26 & 0.52 & 0.48 & 0.26 \\
Sum & & & & & & & \\
Sum Sq. Dev. & $134,102.80$ & $122,797.10$ & 105.11 & $55,751.40$ & $402,296.40$ & $24,014.72$ & 55.41 \\
Observations & 55.00 & 55.00 & 55.00 & 55.00 & 55.00 & 55.00 & 55.00 \\
\hline
\end{tabular}

(Source: Author's Computation Aided by E-views Version 9)

Correlation Analysis: From table 2, it can be inferred that credit policy is positively related to cash conversion cycle and return on assets. However, there exists a negative relationship between credit policy and size, return on capital employed, natural logarithm of operating cash flow as well as returns on equity. Cash conversion cycle is inversely related to all the proxies of profitability, including size of firms. 
Table 2: Results of Correlation Analysis

\begin{tabular}{llllllll}
\hline & CP & CCC & ROA & ROCE & ROE & SIZE & LNOCF \\
\hline CP & 1.000 & 0.892 & 0.004 & $(0.022)$ & $(0.484)$ & $(0.115)$ & $(0.333)$ \\
CCC & 0.892 & 1.000 & $(0.097)$ & $(0.171)$ & $(0.536)$ & $(0.216)$ & $(0.402)$ \\
ROA & 0.004 & $(0.097)$ & 1.000 & 0.497 & 0.409 & 0.083 & 0.214 \\
ROCE & $(0.022)$ & $(0.171)$ & 0.497 & 1.000 & 0.291 & 0.315 & 0.405 \\
ROE & $(0.484)$ & $(0.536)$ & 0.409 & 0.291 & 1.000 & $(0.017)$ & 0.045 \\
SIZE & $(0.115)$ & $(0.216)$ & 0.083 & 0.315 & $(0.017)$ & 1.000 & 0.351 \\
LNOCF & $(0.333)$ & $(0.402)$ & 0.214 & 0.405 & 0.045 & 0.351 & 1.000 \\
\hline
\end{tabular}

(Source: Author's Computation Aided by E-views Version 9)

\section{Hypothesis One}

$\mathrm{H}_{0}$ : Credit policy has no significant effect on profitability of manufacturing companies in Nigeria.

$\mathrm{H}_{1}$ : Credit policy has a significant effect on profitability of manufacturing companies in Nigeria.

Interpretation: Results in table 3 revealed that credit policy is positively related to return on assets. As indicated in the table, the fixed effect results are appropriate based on the coefficient and p-value shown by the Hausman test. The coefficient of 0.1625 is however not statistically significant at $5 \%$ level of significance. As shown in table 4, the random effect is appropriate as the p-value of 0.4764 is higher than 0.05 . There is a positive relationship between credit policy and return on equity. The coefficient of 0.042205 is also not statistically significant at the same level of confidence as used in table 4 . As revealed in table 5, the fixed effect is appropriate considering the fact that the $p$-value of the Hausman test is less than 0.05 . The nature of the relationship between credit policy and return on capital employed is equally positive. However, the coefficient of 0.162567 is also not statistically significant. In summary, the above findings have demonstrated that credit policy is positively related to all the metrics of profitability. It however does not have significant effect on profitability, unless when its impact is combined with other variables such as cash conversion cycles, size of firms and operating cash flows. The finding here is consistent with the conclusions of Owolabi \& Obida (2012) who investigated liquidity and profitability relationships in selected manufacturing companies and found liquidity management significantly impacting on profitability.

Pandey and Jaiswal (2011) examined the link between profitability and liquidity using NALCO as a case study and the various working capital ratios were found that have statistically insignificant impacts on the ROCE of the company. Afeef (2011) analyzing the Impact of Working Capital Management components on the Profitability of SME's in Pakistan, established that working capital management measures had a perceptible impact on profitability measured by return on assets of firms. In Nigeria, Egbide \& Enyi (2009)) studied the correlation between the components of working capital and profitability measured by Return on assets using a sample of 25 Nigerian non-financial firms for the 2005 and 2006 period and discovered that only debtors collection periods have a significant negative association with profitability while others were positively correlated. Also, in agreement with Samiloglu and Demirgunes (2008)) who investigated the relationship among Istanbul firms and established that growth in sales affects firm profitability positively. This result support the view that liquidity and profitability are directly associated since liquidity is enhanced by sale's growth.

\section{Hypothesis Two}

$\mathrm{H}_{0}$ : Cash flow management has no significant effect on profitability of manufacturing companies in Nigeria. $\mathrm{H}_{1}$ : Cash flow management has significant effect on profitability of manufacturing companies in Nigeria.

Cash flow management is proxied by operating cash flow and cash conversion cycles. Cash conversion cycles are negatively related to all the metrics of profitability employed by the study (such as returns on assets, return on equity and returns on capital employed.). While the coefficient of -1.172402 in table 4 is statistically significant under random effect, the coefficients of -0.083317 and -0.005915 are not statistically significant, all at $5 \%$ level of significance. Operating cash flow is negatively related to returns on assets and returns on equity, while it is positively related to returns on capital employed. All the coefficients of -0.0505253 , 10.80033 and 2.436309 in table $3,4 \& 5$ are not statistically significant. However, when combined with the 
other variables, they are statistically significant at $5 \%$ in relation to their impact on return on equity, returns on capital employed by at significant at $10 \%$ in relation to return on asset. These are evidenced by the FStatistics (p-values) of $1.930955(0.07789)$ for return on assets, $6.126573(0.0000431)$ for return on equity and $6.067481(0.0000025)$ for returns on capital employed. This finding is equally consistent with Makori and Jagongo (2013) who found a negative relationship between cash conversion cycles and profitability. This finding is equally consistent with the findings of Kania and Bacon (2005)) and Lazaridis \& Dimitrois (2006) who studied the impact of profitability, growth, risk, liquidity and expansion on the dividend decision/policy of a corporation. This finding can be linked to the study of Eljelly (2004), Shin \& Seonen (1998), (Eljelly, 2004) examines a sample of 29 joint stock companies in Saudi Arabia and found a negative relationship between liquidity and profitability.

Falope \& Ajilore (2009) also found a negative correlation between working capital and profitability among Nigerian firms. Manohar and Ashokkumar (2010)did a case study of Cement Industry in Tamilnadu and established a significant negative relation between the firm's profitability and its liquidity level. Also, Bhunia and Brahma (2011) studied the significance of liquidity management on profitability and found a substancial negative relationship between the profitability measured by ROCE and all the independent variables (CR, LR, ALR, DER, AOI, AOD, and AOC) except for CR which indicated a positive influence on profitability. Shin and Seonen (1998) investigated a sample of 58,985 listed companies in America for a period of twenty years and established a negative relationship between the net trade cycle (cash conversion cycle) and corporate profitability. Gill, Biger and Mathur (2010) found a positive relationship between cash conversion cycle and profitability amongst firms in the United States. Lazaridis and Dimitrios (2006) studied a sample of 131 listed firms for the period 2001-2004. They found a strong negative relationship between profitability and CCC. Deloof (2003)) found a positive relationship between cash conversion cycle and ROA and ROE. He asserted that a longer cash conversion cycle might increase profitability because it leads to higher sales. This argument is in tandem with the findings of Lazaridis \& Lyroudi (2000) who investigated the link among the food industry in Greece and established a positive and significant relationship between the CCC and profitability (measured by ROI and NPM). From the findings it can be deduced that a longer cash conversion cycle can improve a company's profits. This was followed by KPMG (2005) which asserted that shortening the CCC releases liquidity and impacts directly on the company's financial position as well as the company's returns.

Table 3: Results of Regression Analysis with Return on Assets (ROA) as Dependent Variable

\begin{tabular}{|c|c|c|c|c|c|c|c|c|}
\hline \multirow[b]{2}{*}{ Variables: } & \multicolumn{3}{|l|}{ Fixed Effects } & \multicolumn{3}{|c|}{ Random Effects } & \multicolumn{2}{|c|}{ Hausman Test } \\
\hline & Coefficients & T-Statistics & P-Value & Coefficients & T-Statistics & P-Value & Statistic & P-Value \\
\hline Constant & 190.4169 & 1.541142 & 0.1301 & -14.91249 & -0.176418 & 0.8607 & \multirow{8}{*}{10.39556} & \multirow{8}{*}{0.0343} \\
\hline $\mathrm{CP}$ & 0.162567 & 0.694765 & 0.4907 & 0.275204 & 1.492203 & 0.1419 & & \\
\hline LNOCF & -0.505253 & -0.127387 & 0.8992 & 4.694962 & 1.397716 & 0.1684 & & \\
\hline $\mathrm{CCC}$ & -0.083317 & -0.362792 & 0.7184 & -0.270245 & -1.356366 & 0.1811 & & \\
\hline SIZE & -7.905813 & -1.471257 & 0.148 & -0.815103 & -0.185382 & 0.8537 & & \\
\hline \multicolumn{7}{|l|}{ OTHERS : } & & \\
\hline F-Statistics & 1.930955 & & 0.07789 & 1.119786 & & 0.357739 & & \\
\hline R-Square & 0.251395 & & & 0.082218 & & & & \\
\hline
\end{tabular}

(Source: Author's Computation Aided by E-views Version 9) 
Table 4: Results of Regression Analysis with Return on Equity (ROE) as Dependent Variable

\begin{tabular}{|c|c|c|c|c|c|c|c|c|}
\hline \multirow[b]{2}{*}{ Variables : } & \multicolumn{3}{|l|}{ Fixed Effects } & \multicolumn{3}{|c|}{ Random Effects } & \multicolumn{2}{|c|}{ Hausman Test } \\
\hline & Coefficients & T-Statistics & P-Value & Coefficients & T-Statistics & P-Value & Statistic & P-Value \\
\hline Constant & 471.6173 & 1.556986 & 0.1263 & 390.656 & 1.885143 & 0.0652 & \multirow{8}{*}{3.509445} & \multirow{8}{*}{0.4764} \\
\hline $\mathrm{CP}$ & -0.464084 & -0.80902 & 0.4227 & 0.042205 & 0.093345 & 0.926 & & \\
\hline LNOCF & -12.06761 & -1.241068 & 0.2209 & -10.80033 & -1.31154 & 0.1957 & & \\
\hline $\mathrm{CCC}$ & -0.678276 & -1.204729 & 0.2345 & -1.172402 & -2.400235 & 0.0201 & & \\
\hline SIZE & -12.71974 & -0.965557 & 0.3393 & -7.915643 & -0.734344 & 0.4662 & & \\
\hline \multicolumn{7}{|l|}{ OTHERS : } & & \\
\hline F-Statistics & 3.471913 & & 0.003279 & 6.126573 & & 0.000431 & & \\
\hline R-Square & 0.376485 & & & 0.328916 & & & & \\
\hline
\end{tabular}

(Source: Author's Computation Aided by E-views Version 9)

Table 5: Results of Regression Analysis with Return on Capital Employed (ROCE) as Dependent Variable

\begin{tabular}{|c|c|c|c|c|c|c|c|c|}
\hline \multirow[b]{2}{*}{ Variables : } & \multicolumn{3}{|c|}{ Fixed Effects } & \multicolumn{3}{|c|}{ Random Effects } & \multicolumn{2}{|c|}{ Hausman Test } \\
\hline & Coefficients & T-Statistics & P-Value & Coefficients & T-Statistics & P-Value & Statistic & P-Value \\
\hline Constant & -5.311946 & -0.081252 & 0.9356 & -97.68579 & -2.184075 & 0.0337 & & \\
\hline $\mathrm{CP}$ & 0.03034 & 0.245053 & 0.8075 & 0.225816 & 2.31404 & 0.0248 & & \\
\hline LNOCF & 2.436309 & 1.160895 & 0.2517 & 5.087546 & 2.862459 & 0.0061 & & \\
\hline $\mathrm{CCC}$ & -0.005915 & -0.048676 & 0.9614 & -0.211093 & -2.00234 & 0.0507 & 24.41228 & 0.0001 \\
\hline SIZE & -0.065756 & -0.023127 & 0.9816 & 3.242086 & 1.393555 & 0.1696 & & \\
\hline \multicolumn{9}{|l|}{ Others : } \\
\hline F-Statistics & 6.067481 & & 0.000025 & 4.283266 & & 0.004666 & & \\
\hline R-Square & 0.513433 & & & 0.255211 & & & & \\
\hline
\end{tabular}

(Source: Author's Computation Aided by E-views Version 9)

\section{Conclusion and Recommendations}

This study investigated the impact of liquidity management on profitability of selected Nigerian listed manufacturing firms. Liquidity management and profitability are key for organizational survival, because excessive or insufficient liquidity may be harmful to the smooth running of the organization so the absence of profit can lead to bankruptcy. An organization with a well-established proper set of liquidity management policies and procedures will increase profits as well as dividend, reduce the risk of corporate failure and significantly improve its chances of survival. Effective liquidity management will enable an organization to derive maximum benefits at minimal cost. Effective liquidity management has a significant relationship with dividend payout ratios. The implications of the above are that liquidity has a low degree of influence on the profitability of manufacturing companies in Nigeria. This confirms inefficiency and incompetence in the management of liquid assets (Egbide, Uwuigbe \& Uwalomwa, 2013; Kaur \& Silky, 2013). It should be noted here that the inverse directional relationship between liquidity management ratios and profitability ratios established the theoretical foundation which posit that profitability and liquidity are inversely related. This study has shown that both illiquidity and excess liquidity are "financial diseases" that can erode the profit base of a manufacturing company as they affect company's attempt to attain high profitability levels.

It is recommended that firms should not only concentrate on the profit maximization concept alone but also employ measures that will ensure effective and efficient management of their liquid assets. Such measures will help to reduce cases of excessive and deficient liquidity and their effects. Managers should strive to achieve a reasonable level of profitability in order to maximize their shareholders wealth. Management of firms should review and oversee credit policy periodically considering their business nature and the credit 
worthiness of customers should be appraised continually without sentiment to know their ability. This will drastically reduce the incidence of bad debts. The operating activities of listed manufacturing companies should be modified so as to be able to finance a greater part of their current liability. Generally, a higher operating cash flow ratio is a better option, but business peculiarities should be taken into consideration. The impact of cash flow analysis is optimized when results are compared to the industrial averages from time to time. Management should strive to keep a low cash conversion cycle. A longer cash conversion cycle may impact negatively on the liquidity of the companies because cash will be tied unnecessarily in inventory or account receivables. Managers should reduce the number of days of accounts receivable and stocks to the minimum level in order to create value for the firms. Companies are capable of gaining a sustainable competitive advantage by means of effective and efficient utilization of the resources of the organization through a careful reduction of the cash conversion cycle to its minimum.

In doing this, the firm's profitability is expected to rise. As a result, managers are advised to generate profits for their companies by handling rightly the cash conversion cycle and maintaining each different component (accounts receivables, accounts payables and inventory) at optimum level (Owolabi \& Obida, 2012). This study equally recommended an effective and efficient management of the component of current assets, especially the accounts receivable and inventory, as this will positively impact on the liquidity level of manufacturing companies in Nigeria. Debt factoring should be encouraged to recover debts receivables that are overdue from customers. Investors on their part should always pay close attention to firms' cash flow statement in order to access the true financial and operational status before committing funds.

\section{References}

Abuzaraman, E. (2004). Liquidity - profitability tradeoff: An empirical investigation in an emerging market. International Journal of Commerce and Management, 14(2), 48-061.

Afeef, M. (2011). Analyzing the impact of working capital management on the profitability of SME's in Pakistan. International Journal of Business and Social Science, 2(22), 173-183

Agbada, A. 0.\& Osuji, C. C. (2013). The Efficacy of Liquidity Management and Bank Performance. International Review of Management and Business Research, 2(1), 222-233.

Ajanthan. A. (2013). A Nexus Between Liquidity \& Profitability: A Study Of Trading Companies In Sri Lanka. European Journal of Business and Management, 5(7).

Ajathan, A. A. (2013). The relationship between dividend payout and firm profitability: a study of selected Hotels and Restaurantcompanies in Sri Lanka. International journal of Scientific andResearch Publication, 3(6), 1-6.

Akoto, R. K., Awunyo-Vitor, D. \& Angmor, P. L. (2013). Working capital management and profitability: Evidence from Ghanaian listed manufacturing firms. Journal of Economics and International Finance, 5(9), 373.

Almazari, A. A. (2013).The Relationship between Working Capital Management and Profitability: Evidence from Saudi Cement Companies. British Journal of Economics, Management \& Trade, 4(1).

Barclay, M. J. \& Smith, C. W. (1988). Corporate payout policy: Cash dividends versus open-market repurchases. Journal of Financial Economics, 22(1), 61-82.

Bhunia, A. \& Brahma, S. B. (2011). Importance of Liquidity Management on Profitability. Asian Journal of Business Management, 3(2), 108-117.

Bhunia, A. (2011). Importance of Liquidity Management on Profitability. mqwertyuiopasdfghjklzxcvbnmrt, 43(1).

Committee of European Banking Supervisors (CEBS) (2009). Interim report on liquidity buffers and survival periods accessed @ www. c-ebs.org/publications.

Deloof, M. (2003). Does working capital management affect profitability of Belgian firms? Journal of business finance \& accounting, 30(3-4), 573-588.

Egbide, B. (2009). Working capital management and profitability of listed companies in Nigeria. Nigeria Research Journal of Accountancy, 1(1), 44-57.

Egbide, B., Uwuigbe, O. \& Uwalomwa, U. (2013). Liquidity Management and Profitability and Profitability in Manufacturing Companies in Nigeria. Journal of Busines and Management, 9 (1), 13-21.

Eljelly, A. M. (2004). Liquidity-profitability tradeoff: an empirical investigation in an emerging market. International Journal of Commerce and Management, 14(2), 48-61. 
Ezejiofor, R. A., Adigwe, P. K. \& John-Akamelu, R. C. (2015). The Credit Management on Liquidity Management and Profitability Position of Manufacturing Companies in Nigeria. European Journal of Reseach and Reflection in Managent Sciences, 3(3), 32-48.

Falope, O. I. \& Ajilore, O. T. (2009). Working capital management and corporate profitability: evidence from panel analysis of selected quoted companies in Nigeria. Research Journal of Business management, 3 (2), 73-84.

Fang, V., Noe, T. H. \& Tice, S. (2008). Stock market liquidity and firm performance: Wall street rule or Wale street rule.

Gill, B. \& Mathur, B. (2010). The relationship between working capital management and profitability: evidence from the United States. Business and Economic Journal, 10, 1-9

Ikpefan, O. A. \& Owolabi, F. (2014). Working capital management and profitability in the manufacturing sector: an emperical investigation of Nestle Nigeria Plc and Cadbury Nigeria Plc. Global Journal of Management and Business Research, 14(4), 21-27

Ilori, K. (2013). Submission on corporate governance- why the business failure in Nigeria, Fin Intel Magazine online www.myfinancialintelligence.com

Kania, S. L. \& Bacon, F. W. (2005). What factors motivate the corporate dividend decision. ASBBS E-Journal, 1(1), 97-107.

Kaur, S. S. \& Silky, J. (2013). A Study on Liquidity and Profitability of Selected Indian Cement Companies: A Regression Modeling Approcah. International Journal of Economics, Commerce and Management, 1(1), 1-24.

KPMG. (2005). International survey of corporate responsibility reporting. KPMG Global sustainability Journal, 1(1), 97-107 kpmg.com.

Lazaridis, I. \& Lyroudi, K. (2000). Short-term financial management of the business in Greece and in Cyprus, Business and Economics Society International.

Lazaridis, I. \& Dimitrious, T. (2006). Relationship between working capital management and profitability of listed companies in the Anthens Stock Exchange. Journal of Financial Management and Analysis, 19 (1), 1-12.

Makori, D. M. \& Jagongo, A. (2013). Working capital management and firm profitability: Empirical evidence from manufacturing and construction firms listed on Nairobi securities exchange, Kenya. International journal of accounting and taxation, 1(1), 1-14.

Manohar, V. \& Ashokkumar, N. (2010). Liquidity Vs Profitability-A Case Study on Inventory Management of Cement Industry in Tamilnadu. Advances In Management. Available in www.mangein.net/bk_issue/abst_3_3.htm

Mba, D. O. \& Eyo, E. I. (2013). Poor financial manageemnt in corporate failure: cause and remedy. Business and Management Research, 2(4), 19-24.

Moulton, H. G. (1918). Commercial banking and capital formation. Journal of Political Economy, 26, 484-508.

Oladipupo, A. \& Okafor, C. (2013). Relative contribution of working capital management to corporate profitability and dividend payout ratio: Evidence from Nigeria. International Journal of Business and Finance Research, 3(2), 11-20.

Oladipupo, A. \& Okafor, C. (2013). Relative contribution of working capital management to corporate profitability and dividend payout ratio: Evidence from Nigeria. International Journal of Business and Finance Research, 3(2), 11-20.

Owolabi, S. A., Obiakor, R. T. \& Okwu, A. T. (2011). Liquidity-Profitability Relationship in Business Organisation: A study of Selected Quoted Companies. British Journal of Economics, Finance and Management Sciences, 1(2), 11-30.

Owolabi, S. A. \& Obida, S. S. (2012). Liquidity management and corporate profitability: case study of selected manufacturing companies listed on the Nigerian Stock Exchange. Business Dynamics, 2(2), 10-25.

Pandey, S. \& Jaiswal, V. K. (2011). Effectiveness of working capital management on profitability. Journal of Indian Management, 8(1), 73-80.

Priya, K. \& Nimalathasan, B. (2013). Liquidity Management and Profitability: A Case Study of Listed Manufacturing Companies in Sri Lanka. International Journal of Technological Exploration and Learning, 2(4), 161-165.

Preston, L. E. \& Post, J. E. (1981). Private management and public policy: the principle of public responsibility. California Management Review, 23(3), 56-62. 
Samiloglu, F. \& Demirgunes, K. (2008). The effect of working capital management on firm profitability: Evidence from Turkey. The International Journal of Applied Economics and Finance, 2(1), 44-50.

Schumpeter, J. (1943). Capitalism, Socialism and Democracy. Unwin, London

Schumpter, J. A. (1943). Business cycle: a theoretical, Historical, and statistical analysis of the capitalist process, McGraw-Hill Book Company Inc., New York.

Schumpter, J. A. [1911] .(2008). The theory of economic development: An inquiry into profits, capital, credit, interest and the business cycle, translated from the Germany by Redvers Opie, New Brunswick (USA) nad London (U.K.): translation publishers.

Shin, H. \& Soenen, L. (1998). Efficiency of working capital nad corporate profitability. Finanacial Practice \& Education, 8(2), 37-45

Umobong, A. A. (2015). The Impact of Liquidity and Profitability Ratios on Growth of Profits in Pharmaceutical Firms in Nigeria. European Journal of Accounting, Auditing and Finanace Research, 3(10), 97- 114.

Uremadu, S. O., Egbide, B. C. \& Enyi, P. E. (2012). Working capital management, liquidity and corporate profitability among quoted firms in Nigeria evidence from the productive sector. International journal of academic research in accounting, finance and management sciences, 2(1), 80-97. 